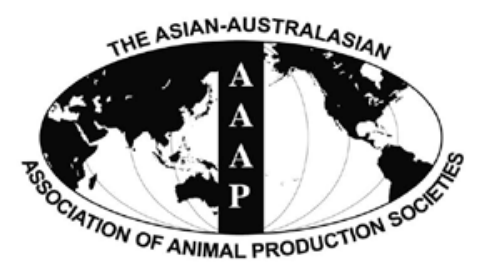

Asian-Aust. J. Anim. Sci.

Vol. 25, No. 1 : 143 - 150

January 2012

www.ajas.info

http://dx.doi.org/10.5713/ajas.2011.11368

\title{
Pork Preference for Consumers in China, Japan and South Korea
}

\author{
S.-H. Oh* and M. T. See ${ }^{1}$ \\ North Carolina Agricultural and Technical State University, Greensboro, NC, USA
}

\begin{abstract}
Competition in global pork markets has increased as trade barriers have opened as a result of free trade agreements. Japanese prefer both loin and Boston butt, while Chinese prefer pork offal. Frozen pork has increased in terms of imports into China. Japanese consumers consider pork meat origin along with pork price when making purchase decisions. While the Chinese prefer a strong tasting pork product, South Korean consumers show very strong preferences to pork that is higher in fat. Therefore, South Korean consumers have a higher demand for pork belly and Boston butt. Consequently, the supply and demand of pork in Korea is hardly met, which means that importation of high fat parts is inevitable. In Korea there is lower preference toward low fat parts such as loin, picnic shoulder, and ham. During the economic depression in South Korea there have been observable changes in consumer preferences. There remains steep competition among the pork exporting countries in terms of gaining share in the international pork market. If specific consumer preferences would be considered carefully, there is the possibility to increase the amount of pork exported to these countries. (Key Words : Pork, Preference, China, Japan, South Korea)
\end{abstract}

\section{INTRODUCTION}

The increase in competition in global pork markets is a result of free trade agreements among countries (Manger, 2005). Pork imports and exports in each country are now part of international trade rather than simply domestic pork supply and demand (Livestock and Poultry, 2011). China is not only the world's largest pork producer with nearly $50 \%$ of the world's total production, but is also the world's largest pork consumer (Pork Checkoff, 2009). Recently the amount of pork imports to China has steadily increased. China's fast growing economy has provided the perfect atmosphere for the Chinese to increase their purchasing power, which has subsequently allowed the swine industry in China to expand quickly over the past decades along with increased pork imports.

Japan has remained the number one country for importation of US pork since the 1990s (Felt et al., 2011). Japan's swine industry has encountered such obstacles as increased production costs and environmental limitations, which has created a situation in which Japan now relies on increased importation of pork to supply their demand. The South Korean swine industry has also suffered. Outbreaks

\footnotetext{
* Corresponding Author : S.-H. Oh. Tel: +1-336-334-7672, Fax: +1-336-334-7288, E-mail: soh@ncat.edu

${ }^{1}$ North Carolina State University, Raleigh, NC, USA.

Received October 14, 2011; Accepted November 20, 2011
}

of foot-and-mouth disease (FMD) have taken its toll on South Korea's pork industry since 2000. The small farming operations in South Korea have suffered the most and subsequently been forced out of operation as a result of an overall decrease in production efficiency. This decrease in production efficiency is a result of higher production costs primarily from increased feed costs and lower market prices, all of which result in reduced profit for the small farmer.

The exporting and importing of pork to countries in order to meet both demand and consumer preference is dependent upon international pork trade. Changes in hog price and production in net exporting countries is directly correlated to the change in demand and preference occurring in net importing countries. The objective of this paper is to review the pork preference for consumers in China, Japan, and South Korea.

\section{Japan}

The pork industry in Japan was almost destroyed after the Second World War. However, as the Japanese regained its economic power, meat consumption and the imports have increased dramatically, which results from free trade in Japan since 1971 (Hoshino, 2006; Felt et al., 2011). Japan produces and consumes pork being the foundation for the food industry, along with rice and vegetables. Swine production is about $21 \%$ of total livestock production in Japan (Swine production report, 2009). Japanese pork cuts 


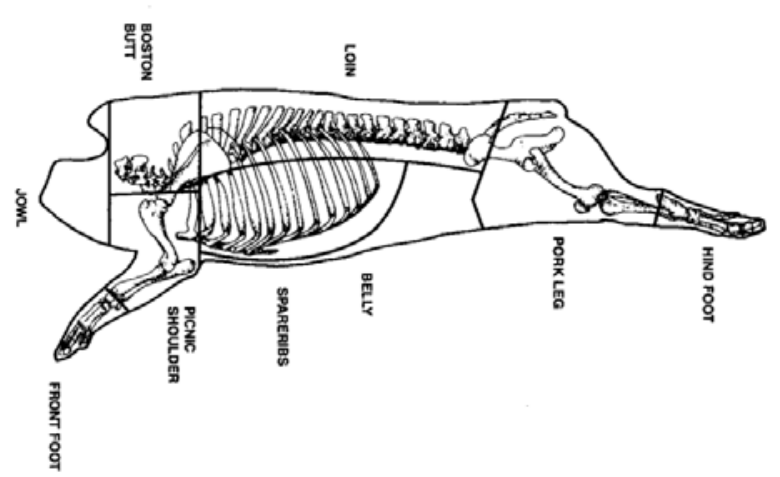

Figure 1. US pork primal cuts. Source: http://www.ansci.illinois.edu

are similar to standard primal cuts in the United States (Figure 1). Only slight differences are observed in the portions of the pork carcass, so to better export that pork product we need to know exactly what part of the pork is consumed and popular in Japan. One of the most well known pork dishes in Japan is pork cutlet or Tonkatsu and shabu shabu which are prepared with Boston butt and loin. The loin is called "rosu" in Japan, which means "roast" in English. This section is similar to the loin in the United States but is not cut exactly the same. "Kata-rosu" (Collar) includes loin muscle from alongside the backbone and portions of the Boston butt. "He-re" is a fillet in beef and tenderloin in pork. Typically this is the most tender cut and is one of the most expensive parts of the pork because only very small amounts are produced. The Boston butt in Japan is referred to as "kata" and this part is used for pork cutlet in Japanese meals. "Bara" includes the spare rib and belly, and the pork leg or ham is referred to as "momo" or "sotomomo" (referred to http://en.wikipedia.org/).

Japan imported more grain products such as wheat and soybeans than meat products in 1960's to 1980's. It started importing more meat products such as beef and pork that steadily increased from the 1990 s to 2000 with economic growth over time (International food supply and demand report, 2009). It indicates that wheat and soybeans have been used as feedstuff for livestock animals, and it has impacted the cost of production in Japan as the feed cost became higher (PIC, 2006), which results in having started to import meat products directly from other countries (Makise, 2002).

Table 1 describes what percentage of each pork product is imported into Japan showing market share of pork cuts and the imported amount of them to Japan. Market share of imported Boston butt and loin is very high followed by ham. One interesting part of this table is the high percentage of imported loin into Japan, which is $39.5 \%$. In other words in Japan loin has the largest gap in supply and demand. Table 2 shows Japanese pork cut supply and demand and the portion of each cut that is supplied by imported pork. The
Table 1. Market share by pork cut in Japan (1988-2000)

\begin{tabular}{lcc}
\hline Pork cut & Market share (\%) & Imported (\%) \\
\hline Boston butt & $25.6-25.8$ & 14.5 \\
Loin & $23.3-23.6$ & 39.5 \\
Tenderloin & $4.2-4.5$ & 6.2 \\
Belly, spare rib & $17.2-17.6$ & 27 \\
Ham, pork leg & $21.1-21.6$ & 8.4 \\
Other & $6.9-8.9$ & 4.4 \\
Total & 100 & 100 \\
\hline
\end{tabular}

Source: Japanese meat trade institute. 2007.

Table 2. Pork supply and demand by cut in Japan (2000; 1,000 metric tons)

\begin{tabular}{lcccc}
\hline Pork cut & $\begin{array}{c}\text { Domestic } \\
\text { supply }\end{array}$ & $\begin{array}{c}\text { Imported } \\
\text { supply }\end{array}$ & $\begin{array}{c}\text { Total } \\
\text { demand }\end{array}$ & $\begin{array}{c}\text { \% of } \\
\text { imported }\end{array}$ \\
\hline Boston butt & 210 & 103 & 313 & 32.9 \\
Loin & 115 & 329 & 444 & 74.0 \\
Tenderloin & 14 & 56 & 70 & 80.0 \\
Belly, spare rib & 190 & 13 & 203 & 6.4 \\
Ham, pork leg & 111 & 127 & 238 & 53.3 \\
\hline
\end{tabular}

Source: Japanese meat trade institute. 2007.

percentage of each imported cut is calculated by imported supply divided by total demand. Loin is the most consumed pork cut, followed by Boston butt and shoulder. An interesting point in this data is that the tenderloin imported percentage is $80 \%$, followed by $74 \%$ of loin being imported into Japan. Spare rib consumption is 200,000 tons of which only $6.4 \%$ is imported to Japan. The demand for spare ribs is met by domestic supply compared to the tenderloin and loin which requires importation of pork from outside of the country.

Table 3 shows percentage of pork cuts compared to the total amount imported by country of origin. This percentage shows the portion of each pork cut within the amount of imported pork from each country. The average most imported part is the loin with $50.7 \%$, followed by spare ribs with $19.4 \%$ and the third is Boston butt with $15.8 \%$. There are other pork parts than loin that is exported into Japan, such as Boston butt, belly, spare ribs, and pork leg, with lots of room to grow in terms of pork exports to Japan. In looking at data from a Japanese consumer survey (Japan meat information service center, 2009), when asked what their preferences were pertaining to pork, consumers answered that origin was of considerable concern when purchasing pork. In other words Japanese consumers demonstrated great concern when purchasing pork as to whether it was produced in Japan or an outside country. Following pork origin, Japanese consumers were concerned with pork price with $49 \%$ importance when purchasing pork. The third most important factor of concern was freshness of the meat with $42 \%$ of importance when purchasing pork. In 
Table 3. Percentage of pork cuts imported by country of origin in 2000

\begin{tabular}{|c|c|c|c|c|c|c|}
\hline & Boston butt & Loin & Tenderloin & Spare rib, belly & Ham, leg & Other \\
\hline US & 6.1 & 71.2 & 14.3 & 3.7 & 2.8 & 1.9 \\
\hline Canada & 14.2 & 66.8 & 11.1 & 0.6 & 2.7 & 4.6 \\
\hline Denmark & 27.7 & 19.2 & 2.7 & 38.9 & 0.4 & 1.1 \\
\hline Ireland & 3.0 & 41.3 & 12.7 & 42.7 & 0.2 & 0.1 \\
\hline S. Korea & 6.8 & 70.5 & 7.1 & - & 15.5 & 0.6 \\
\hline Mexico & 28.2 & 36.1 & 8.6 & 13.9 & 3.4 & 9.8 \\
\hline Netherlands & 7.3 & 36.7 & 9.0 & 38.1 & 0.4 & 8.5 \\
\hline France & 4.2 & 34.6 & 8.1 & 40.0 & 0.5 & 12.6 \\
\hline Other & 7.2 & 43.7 & 6.8 & 36.2 & 0.6 & 5.5 \\
\hline Average & 15.8 & 50.7 & 8.7 & 19.5 & 2.1 & 3.2 \\
\hline
\end{tabular}

Source: Japanese meat trade institute. 2007.

the survey, $57 \%$ of individuals considered beef to be an important factor in human stamina, followed by $66 \%$ of individuals perceiving that pork played a vital role in abundance of vitamin B1. Consumers preferred pork loin (51.5\%) as compared to beef fillet (45\%), which is the tender part of the beef.

Table 4 shows meat imports by year into Japan, with three categories; beef, pork, and poultry. One of the important points obtained from this table is, unlike beef and poultry, pork has continued to increase in imports over the years. The steady increase in pork imports is from 700,000 tons to 872,000 tons from 2001 to 2005 . Based on this table, there has been an increasing demand for pork by Japanese consumers.

\section{China}

Chinese average per capita weekly pork purchases in kilograms is presented in Figure 2 with pork preferences amongst pork parts being relatively evenly distributed with pork offal and ribs each representing $0.25 \mathrm{~kg}$, pork loin representing $0.19 \mathrm{~kg}$, followed by pork shoulder at $0.15 \mathrm{~kg}$, ground pork at $0.13 \mathrm{~kg}$, pork leg at $0.8 \mathrm{~kg}$, pork belly at 0.2 $\mathrm{kg}$, and pork backbone at $0.1 \mathrm{~kg}$ (Ortega et al., 2009). Interestingly the Chinese preference in pork cuts is complementary to that of the Western preferred pork cuts. The most consumed portion within the Western style cuts is the ribs at $0.25 \mathrm{~kg}$ per week, followed by the pork belly at $0.2 \mathrm{~kg}$ and loin at $0.19 \mathrm{~kg}$ per week. This trend has been observed for a long time with the Chinese and Western pork consumption being complementary. In other words, the

Table 4. Meat imports by year in Japan (1,000 metric tons)

\begin{tabular}{lllc}
\hline Year & Beef & Pork & Poultry \\
\hline 2001 & 674 & 708 & 533 \\
2002 & 486 & 777 & 537 \\
2003 & 576 & 752 & 479 \\
2004 & 432 & 863 & 359 \\
2005 & 460 & 872 & 428 \\
\hline
\end{tabular}

Source: Japanese meat trade institute. 2007.
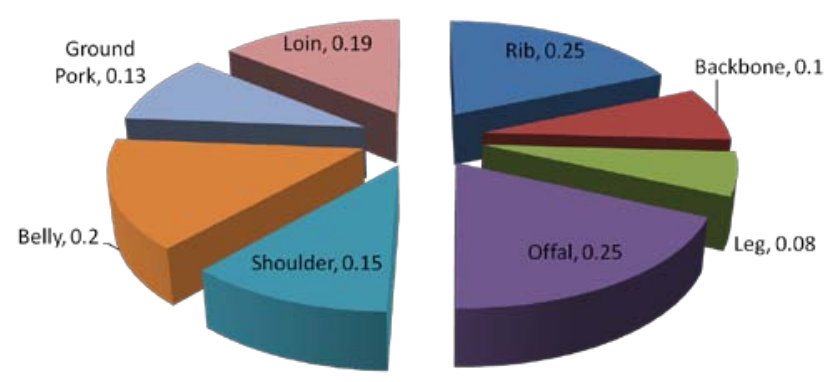

Figure 2. Average per capita Chinese weekly purchase of pork in kg. Source: Ortega et al., 2009.

Western consumer likes lean meat, while the Chinese consumer likes fat cuts such as pork offal (Wang et al., 1998).

As a result, pork offal became a very important market for countries exporting to China (Amponsah et al., 2003). In 2008 there were 553 million US dollars coming into the US from the export of pork offal (Table 6). In 2008 China was ranked 10th in the world for international pork markets with a value of 1.1 billion dollars, which was a $135 \%$ increase from 2007. The United States along with 19 other countries are responsible for exporting pork to China (Table 5). Other sources also demonstrate a similar trend in the increase in pork offal in China alongside the increase of export value over time (Table 7).

Table 5. Top pork suppliers to China (2008; US\$ million)

\begin{tabular}{lcccc}
\hline & US & Canada & Denmark & France \\
\hline Frozen ham & 188 & 33 & 0.9 & 4 \\
Frozen pork offal & 124 & 48 & 189 & 181 \\
Frozen pork & 124 & 30 & 69 & 67 \\
Frozen swine liver & 3 & 0.9 & 0.4 & 0.7 \\
Pig fat & 2 & 4 & 4 & 6 \\
Frozen pork carcass & - & - & 0.5 & 0.5 \\
Prepared pork & 0.4 & - & - & - \\
\hline
\end{tabular}

Source: Inside China Pork Trade. 2009. Canada. 
Table 6. China's pork and products imports (2008)

\begin{tabular}{lcc}
\hline & $\begin{array}{c}\text { World } \\
\text { (US\$ Million) }\end{array}$ & Top supplier \\
\hline Frozen edible pork offal & 553 & Denmark \\
Frozen pork & 296 & US \\
Frozen hams and shoulders, bone in & 227 & US \\
Pig fat & 16 & France \\
Frozen swine livers & 5 & US \\
Prepared pork & 1 & US \\
Total & 1,100 & US \\
\hline
\end{tabular}

Source: Inside China Pork Trade. 2009. Canada.

Figure 3 presents a comparison of the 2007 and 2008 Chinese pork import data showing a one year increase. For example, frozen pork increased by $5.73 \%$. Pig fat increased 4.3\%, while frozen liver increased 4 times from 2007 to 2008. When looking at the dramatic changes in terms of pork imports for China, there lies the possibility for higher importation of various pork parts. Figure 4 shows pork imports into China with the most dramatic increase in pork exports from the United States into China since 2006.

The top pork suppliers to China in 2008 are shown in Table 5, with the United States ranked first for many pork parts. However, Denmark and France have increased their market share with 189 million tons and 181 million tons, respectively, especially in frozen pork offal. Frozen pork offal imports are a much bigger category than imports for frozen pork carcass and frozen hams. When discussing trade with China, pork offal is the most important product exported to China. A lesson that can be learned here from the fact that Denmark and France have a large market share for pork supply to China, especially pork offal, is that countries exporting pork need to develop marketing strategies for specific portions of pork cuts preferred by the Chinese consumer.

Table 8 represents price comparisons for pork cuts and variety meats in China and the US. When the ratio is greater

Table 7. Hog offal trade in China

\begin{tabular}{lcccc}
\hline Year & $\begin{array}{c}\text { Export } \\
\text { volume } \\
\text { (metric ton) }\end{array}$ & $\begin{array}{c}\text { Import } \\
\text { volume } \\
\text { (metric ton) }\end{array}$ & $\begin{array}{c}\text { Export } \\
\text { value } \\
\text { (US\$ 1,000) }\end{array}$ & $\begin{array}{c}\text { Import } \\
\text { value } \\
\text { (US\$ 1,000) }\end{array}$ \\
\hline 2000 & 1,050 & 101,126 & 1,145 & 48,082 \\
2001 & 410 & 109,642 & 528 & 56,687 \\
2002 & 126 & 74,516 & 165 & 47,853 \\
2003 & 33 & 162,774 & 43 & 104,186 \\
2004 & 177 & 220,530 & 164 & 182,390 \\
2005 & 357 & 168,740 & 296 & 145,662 \\
2006 & 574 & 194,919 & 504 & 134,338 \\
2007 & 40 & 387,313 & 33 & 342,146 \\
2008 & 14 & 540,320 & 22 & 558,415 \\
\hline
\end{tabular}

Source: China's Pork Industry: Recent Trends and Implications for World Meat Trade and Grains Trade. Informa Economics.



Figure 3. Top Chinese pork import changes 2008/2007. Source: Inside China Pork Trade. 2009. Canada.

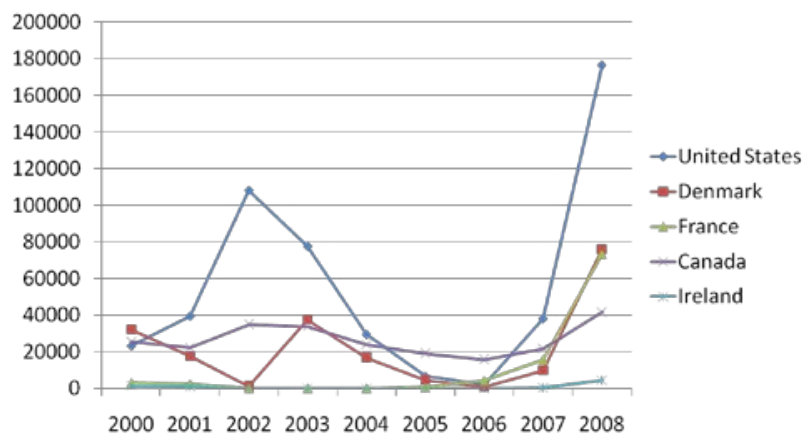

Figure 4. China pork imports from 2000 to 2008 (1,000 MT). Source: China's Pork Industry: Recent Trends and Implications for World Meat Trade and Grains Trade. Informa Economics.

than 1 that indicates the meat is more expensive and when the ratio is less than 1 the meat is less expensive. When looking at US price, the pork part that is more desirable in China is less expensive in the US. The opposite is true for China; the part that is more desirable in the US is less expensive in China. In Chinese dishes there can be found very small pieces of strong tasting pork products and Chinese consumers are willing to pay more to obtain those pork parts. The pork stomach is 0.50 cents more valuable than the loin, while kidney and tongues are 0.30 cents more valuable than loin.

\section{South Korea}

Korean consumer's also have strong preferences for particular parts of the pig. Consequently the supply and demand of those pork parts are hardly met in South Korea. There is high demand for pork portions containing high fat content such as the belly and Boston butt and decreased preference for the low fat parts such as loin, picnic shoulder, and ham (Vonada et al., 2000). Therefore, the importation of high fat parts is inevitable for the Korean consumer. South Korean primary cuts differ slightly from US cuts in that they are more specific. The most preferred part in South Korea is the belly and Boston butt. The South Korean's favorite pork belly dish is called "Sahm-Gyeop-Sahl". If a 
Table 8. Price comparison for pork cuts and variety meats in China and the US

\begin{tabular}{lcccc}
\hline & $\begin{array}{c}\text { China price } \\
(\$ / l b)\end{array}$ & $\begin{array}{c}\text { Ratio of product price to } \\
\text { loin price in China }\end{array}$ & $\begin{array}{c}\text { US price } \\
(\$ / l b)\end{array}$ & $\begin{array}{c}\text { Ratio of product price to } \\
\text { loin price in US }\end{array}$ \\
\hline Loin & 1.20 & - & 1.32 & - \\
Lung & 0.24 & 0.20 & 0.03 & 0.02 \\
Pork stomach & 2.16 & 1.50 & 0.54 & 0.40 \\
Pork kidney & 1.56 & 1.30 & 0.17 & 0.13 \\
Lard & 0.72 & 0.60 & 0.25 & 0.19 \\
Feet & 0.87 & 0.73 & 0.20 & 0.15 \\
Boneless butt & 1.20 & 1.00 & 0.81 & 0.61 \\
Ham & 1.27 & 1.06 & 0.84 & 0.63 \\
Tongue & 1.61 & 1.35 & 0.55 & 0.41 \\
Small intestine & 0.70 & 0.50 & - & - \\
Large intestine & 0.38 & 0.31 & - & - \\
Nape of neck & 1.32 & 1.10 & 0.10 & - \\
Head mask & 0.33 & 0.28 & - & 0.07 \\
\hline
\end{tabular}

Source: The Chinese Market for US Pork Exports. 1997. Iowa State University.

market pig is slaughtered at around 100 to $110 \mathrm{~kg}, 48 \%$ of the carcass would be dressed for meat. Out of the dressed carcass about $40 \%$ would be the belly, Boston butt, and ribs. Another popular dish in South Korea using pork is called "Jok-Bahl” that is steamed pig hocks.

Figure 5 shows Korean consumer preference by pork part, the blue line represents the belly, which is one of the most consumed parts, representing 33\% of all the pork consumed in South Korea. The Boston butt represents the second most consumed portion of pork, with the rib ranking third. Figure 6 shows the inventory rate of pork loin, picnic shoulder, loin, ham, and belly from 2003 to 2008. Inventory rate is interpreted as when you have more pork in inventory than is consumed by the customer the higher the percentage will be. The belly was less than $20 \%$ and rose to slightly more than 30\% in 2005 and goes down to around 20\% where it remains. In other words the lower inventory rate for belly indicates that Koreans consumed more bellies than other parts of the pig.

Figure 7 shows the type of pork imported to South Korea in 2008. In terms of frozen pork the European Union

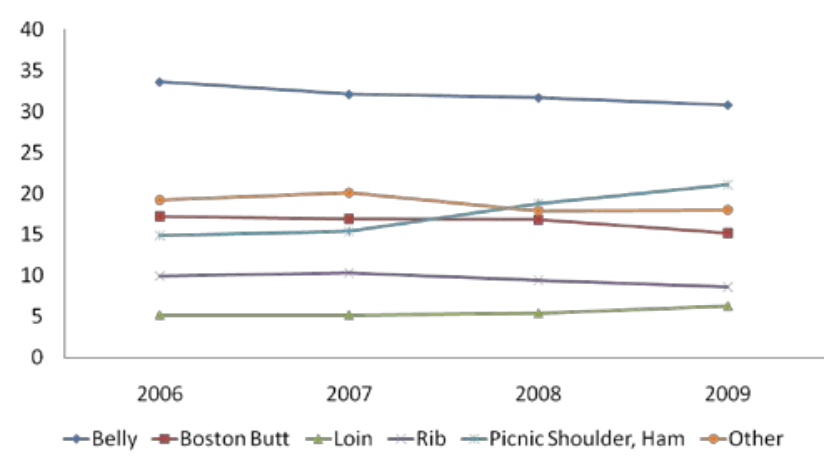

Figure 5. Consumer preference by pork parts in South Korea (\%). Source: TNS world (In 2009, until September).

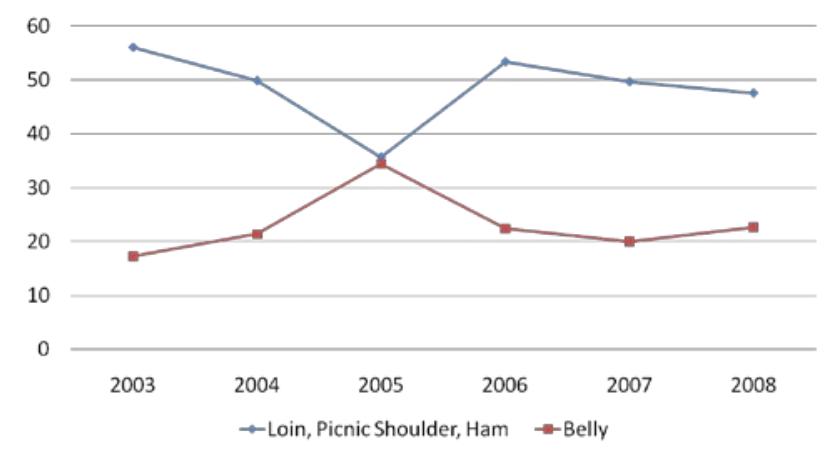

Figure 6. Inventory rate of pork loin, picnic shoulder, ham, and belly (\%). Source: Korea Swine Association. 2009.

was responsible for $41 \%$ of all imported pork to South Korea, followed by the United States with 32\%. Fresh pork imports are a different story. The United States is responsible for $58 \%$ of all fresh pork imported into South Korea during this time, followed by others at 37\%. For frozen pork, the primary part imported into South Korea from the European Union was the belly, which represented $91 \%$ of the total frozen pork exported to South Korea. On the other hand the portion of pork belly was only $14 \%$ out of the total frozen pork imported from United States. Most

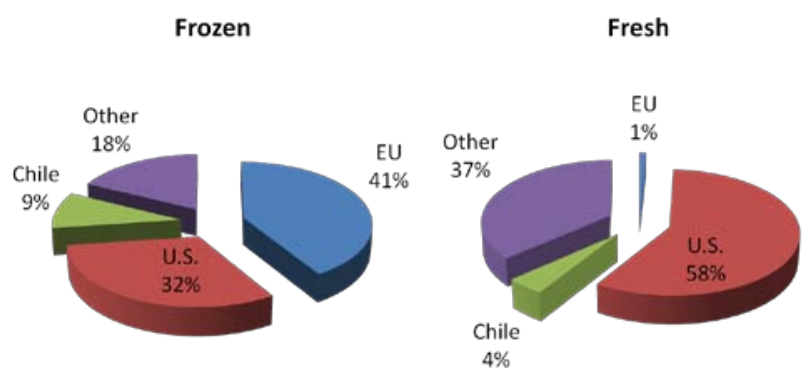

Figure 7. Type of imported pork in South Korea (2008). Source: Korea Swine Association. 2010. 




Figure 8. Imports by pork parts in South Korea. Source: Korea Swine Association. 2009.

frozen pork exports from the United States into South Korea are Boston butts representing $50 \%$ and the picnic shoulder representing 28\%. In a comparison of the US and EU exports to South Korea, their strategies for efficiently targeting the South Korean consumer differ. The EU generally does a better job at meeting the desires and needs of the South Korean consumers.

In 2008, imported pork into South Korea was 214 thousand tons and has remained fairly stable since 2006 with 211 thousand tons, and in 2007 with 247 thousand tons. Of those whole imported pork parts, the "Sahm-GyeopSahl" is about $50 \%$ of all imported pork parts. If combined with Boston butts, it would increase to about $70 \%$ of all the imported pork parts. Although the belly and Boston butt contain higher fat, those parts are highly desired in South Korea. In the mean time, the domestic inventory rate for the lower fat containing pork parts is almost $50 \%$, which means the Korean consumer has a high preference for the higher fat containing parts of the pig (Figure 8). Pork bellies and Boston butts are imported more on an annual basis into South Korea. As the pork belly and Boston butt increases in imports from other countries the rate of domestic supply for pork has decreased annually. The rate of domestic supply in 2003 was $92.8 \%$ and decreased steadily to $76.8 \%$ in 2008 .

Figure 9 shows the countries that exported pork belly to South Korea in 2008. The EU exported $74 \%$ of the total frozen pork belly imported to South Korea, but the United
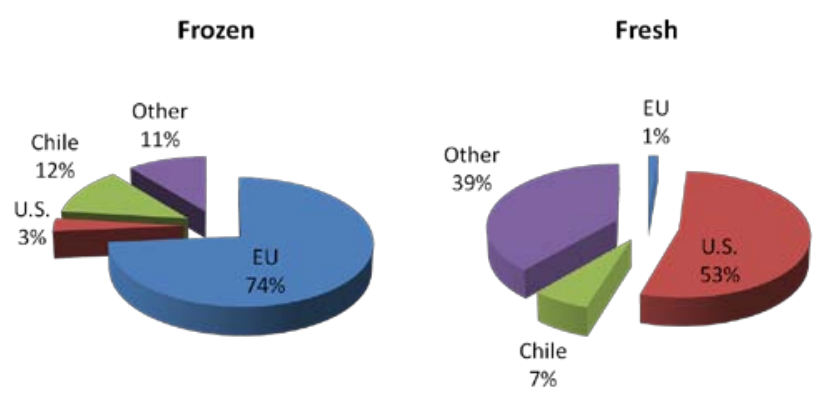

Figure 9. Countries exporting pork belly in South Korea (2008). Source: Korea Swine Association. 2010.

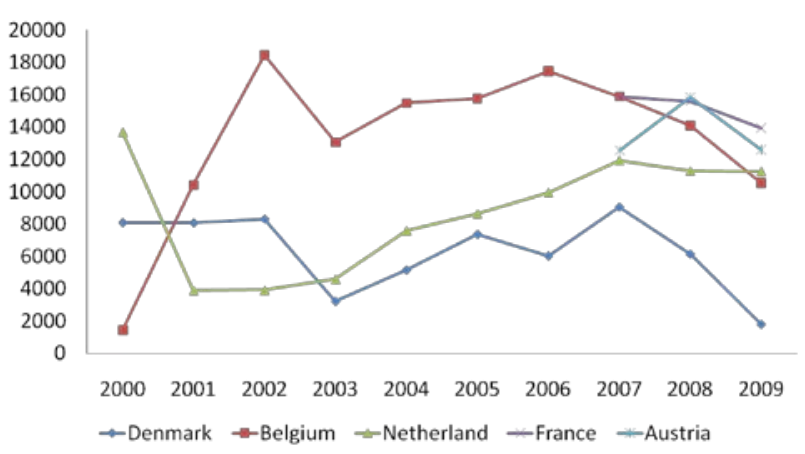

Figure 10. EU countries exporting pork belly to South Korea. Source: Korea Swine Association. 2010.

States exported 53\% of the total fresh pork belly exported to South Korea. About 38\% of pork imported into South Korea comes from the EU, which accounts for $10 \%$ of the total pork market in South Korea. The reason for the EU being such an integral part of South Korea's pork market is because the price of the pork is only $66 \%$ of the price of domestic pork in South Korea, which is 34\% cheaper than pork produced in South Korea (Economic Review, 2009).

The EU mainly exports frozen pork belly, which accounts for about $74 \%$ of the total amount of pork belly imported into South Korea. Figure 10 shows the top 5 countries within the EU that are responsible for exporting pork belly to South Korea. Starting in 2000, Denmark, Belgium, and Holland are the top 3 countries that exported pork belly to South Korea. In 2007, France and Austria also became competitors in the pork belly export market to South Korea. Denmark has decreased the amount of pork being exported to South Korea this is a result of their pork industry structural crisis. In 2009 France became one of the primary countries responsible for exporting pork to South Korea, followed by Austria. Looking at the French exporting strategy, they reduced their price significantly for targeting consumers in Japan and South Korea, improving the amount of exports to those countries.

The consumer eating preference report for South Korea shows that South Koreans prefer grilled pork belly when eating out, followed by grilled Boston butt (Figure 11).


Figure 11. Preferable parts when eating out in South Korea. Source: Korea Swine Association. 2009. 


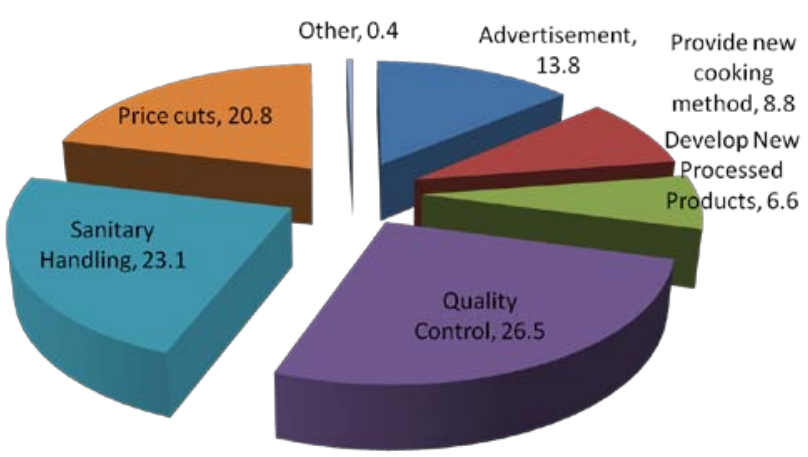

Figure 12. Ways to promote pork consumption in South Korea. Source: Korea Swine Association. 2009.

Remembering that South Korean pork preference is geared towards higher fat pork this correlates with the consumer preference report in that pork belly and Boston butt are two of the main pork parts high in fat.

Figure 12 shows the survey results from the South Korean Swine Industry in 2009 which gathered data with the goal to increase domestic pork consumption. Based on the survey data, about $25.6 \%$ of the South Korean consumers state that quality control is the most effective way to promote consumption of pork, followed by sanitary handling at $23 \%$, and price of cuts at $20 \%$. Another survey by the South Korean Swine Industry shows that 36\% of South Koreans perceive the most pressing issue when purchasing pork is safety and freshness of the pork, followed by pork price at $21.8 \%$, and country of origin at 20.3\% (Figure 13). In the mean time, some researchers have reported that about $50 \%$ of the Korean consumers chose the marbled pork in the survey of selecting preferred pork chops from given images (Cho et al., 2007; Ngapo et al., 2007).

The South Korean consumer is very conscientious about where their purchased pork originates. In a consumer study, $47 \%$ of South Koreans check the label of pork products to determine where the pork originated from, whether from South Korea or another country. This behavior is fairly natural from the result of the study that consumers put more

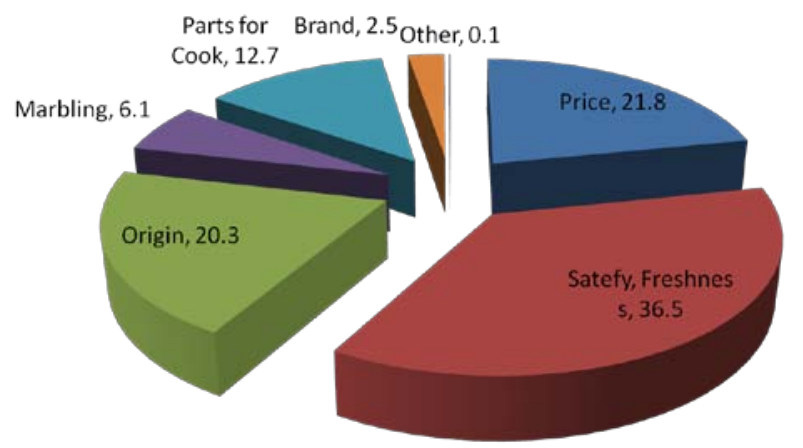

Figure 13. Considerations when purchasing pork in South Korea (\%). Source: Korea Swine Association. 2009.

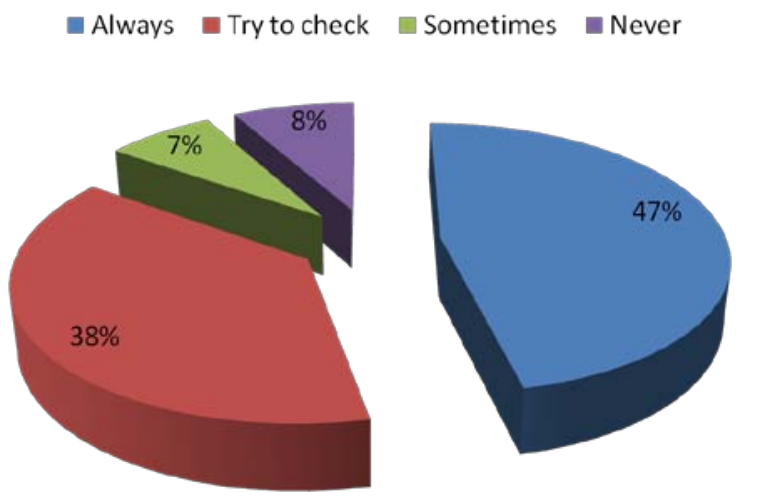

Figure 14. Checking domestic pork when purchasing in South Korea. Source: Korea Swine Association. 2009.

preferences on branded products (Ubilava et al., 2011). The data (Figure 14) further supports the notion that South Korean consumers place a high importance on where their purchased pork originates from, particularly placing a higher preference on domestic pork. In other words, imported pork is in greater competition with domestic pork purchased within the country. The importance of this data to countries exporting pork to South Korea is that a better and more desirable image should be portrayed to South Korean consumers of their pork, paying particular attention to quality control, sanitation and handling methods, and freshness of the pork products.

An interesting result (Figure 15) is what the consumer recognition of domestic pork was after being exposed to particular advertisements. More than half of the consumers answered that they have a better recognition of domestic pork after being exposed to advertisements, which means that there is a relationship between advertisement and consumer recognition among South Korean consumers; $12 \%$ had much better and $50 \%$ had better recognition of domestic pork after having been exposed to advertisements. In total almost $70 \%$ have a better recognition of domestic pork products following exposure to advertisements. Kim et

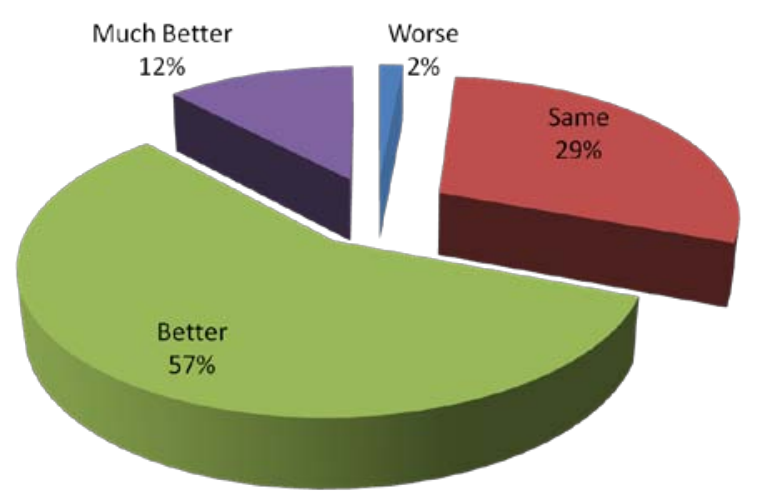

Figure 15. Consumer recognition of domestic pork after being exposed to the advertisements. Source: Korea Swine Association. 2009. 


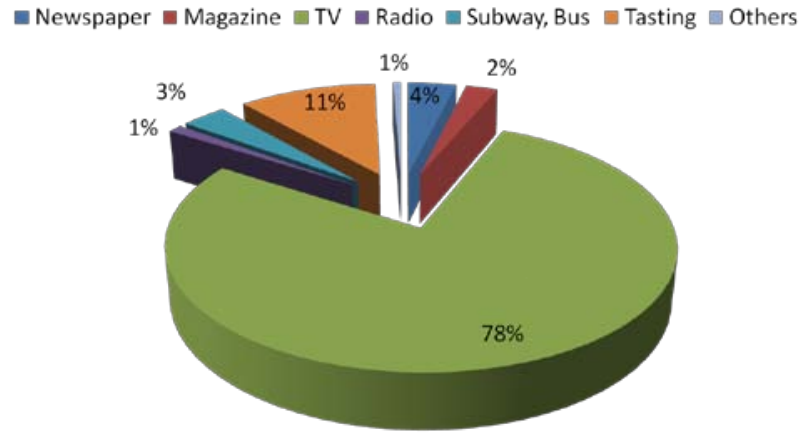

Figure 16. Advertisement for promoting pork consumption in South Korea. Source: Korea Swine Association. 2009.

al. (2007) also have reported the same results about the effect of pork advertisement in South Korea.

Other survey data (Figure 16) show a similar association with advertisements for promoting pork consumption amongst South Koreans. When asked to report which method was the most suitable for promoting pork consumption about $78 \%$ of the South Korean consumers reported that television advertisements were most effective followed by $11 \%$ indicating tasting of the product was important in promotion of pork consumption. These data give a very good indication for pork exporting stakeholders as to methods for increasing imported pork consumption and exports to South Korea.

\section{CONCLUSION}

Japanese prefer both loin and Boston butt, while Chinese prefer pork offal. Frozen pork has increased in terms of imports into China. Japanese consumers consider pork meat origin along with pork price when purchasing pork. While the Chinese prefer a strong tasting pork product, South Korean consumers show very strong preference to certain parts of pork. South Korea has a higher demand for pork belly and Boston butt as it is higher in fat. Consequently, the supply and demand of pork in Korea for particular cuts is hardly met, which means that importation of high fat parts is inevitable. There is lower preference toward low fat parts such as loin, picnic shoulder, and ham. During the economic depression in South Korea there have been observable changes in consumer preferences. There remains steep competition among the pork exporting countries in terms of gaining share in the international pork market. If specific consumer preferences are considered carefully, there will be more possibilities to increase the amount of pork exported to these countries.

\section{REFERENCES}

Amponsah, W. A., X. D. Qin and X. Peng. 2003. China as a potential market for US pork exports. Review of Agricultural
Economics. 25(1):259-269.

China's Pork Industry: Recent Trends and Implications for World Meat Trade and Grains Trade. 2008. Informa Economics.

Cho, S., B. Park, T. Ngapo, J. Kim, E. Dransfield, I. Hwang. 2007. Effect of meat appearance on South Korean consumers' choice of pork chops determined by image methodology. J. Sens. Stud. 22:99-114

Economic Review - The South Korean-EU Free Trade Agreement Negotiations: Some Observations. 2009. Bank of Tokyo Mitsubishi UFJ.

Felt, M., J. Gervais and B. Larue. 2011. Market power and import bans: the case of Japanese pork imports. Agribusiness. 27(1):47-61.

Fukase, M. 2007. The basic consideration of our country pork distribution. Japanese meat trade institute.

Hoshino, T. 2006. Research report of commodity export industries in Latin America. Asia Economy Institute.

Kim, M. K., J. S. Park and K. S. Jeong. 2007. The Price Effect Analysis of Generic Pork Advertisement. Korean Journal of Agricultural Management and Policy. 34(2):389-401.

Korea Meat Trade Association. 2010. http://www.kmta.or.kr.

Korea Swine Association. 2009-2010. http://www.koreapork.or.kr.

Inside China Pork Trade. 2009. Canada

International food supply and demand report. 2009. Japanese Ministry of Agriculture, Forestry and Fisheries.

Japan meat information service center. 2009. http://www.jmi.or.jp/ info/survey_files/file0/46.pdf

Livestock and Poultry: World Markets and Trade. 2011. USDA.

Makise, K. 2002. Maintaining and expanding pork export to Japan. Advances in Pork Production. 13:5-15.

Manger, M. 2005. Competition and bilateralism in trade policy: The Case of Japan's Free Trade Agreements. Review of International Political Economy 12(5):804-828.

Ngapo, T. M., J.-F. Martin and E. Dransfield. 2007. International preferences for pork appearance: I. Consumer choices. Food Qual. Prefer. 18:26-36.

Ortega, D., H. Wang and L. Wu. 2009. Assessing consumer preferences and attitudes toward imported pork in Urban China. International Association of Agricultural Economists Conference, Beijing, China.

PIC. 2006. PIC worldwide survey. PIC company.

Quick Facts: The Pork Industry at a Glance. 2009. Pork checkoff.

Swine production report. 2009. Japanese Ministry of Agriculture, Forestry and Fisheries.

The Chinese Market for US Pork Exports. 1997. Iowa State University.

Ubilava, D., K. A. Foster, J. L. Lusk and T. Nilsson. 2011. Differences in consumer preferences when facing branded versus non-branded choices. J. Consumer. Behav. 10:61-70.

Vonada, M. L., B. S. Bidner, K. E. Belk, F. K. McKeith, W. R. Lloyd, M. E. O’Connor, and G. C. Smith. 2000. Quantification of pork belly and Boston butt quality attribute preferences of South Korean customers. J. Anim. Sci. 78:2608-2614.

Wang, Q., F. Fuller, D. Hayes and C. Halbrendt. 1998. Chinese consumer dem and for animal products and implications for US Pork and poultry exports. J. Agricultural and Applied Economics. 30:127-140. 